\title{
Gastropods of the family Lymnaeidae (Pulmonata) in the littoral zone and Spirogyra blooms from the northwest of Lake Baikal
}

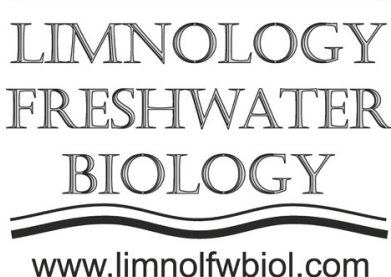

www.limnolfwbiol.com

\author{
Zhuykova N.S. ${ }^{1,2}$ \\ ${ }^{1}$ Irkutsk State University, Irkutsk, Russia \\ ${ }^{2}$ Limnological Institute, Siberian Branch of the Russian Academy of Sciences, Ulan-Batorskaya Str., 3, Irkutsk, 664033, Russia
}

ABSTRACT. Palearctic Radix auricularia (Linnaeus, 1758) inhabiting open littoral zone near the Zarechnoye settlement (6 km from the Severobaikalsk town) identified from anatomy show a high shell variability and can be subdivided into two morphs: with low and high spire. The empty shells of this species have been found over the past six years within green algae washed ashore of this area.

Keywords: Radix auricularia, open littoral zone, shell variability

Approximately 180 species of Mollusca were recorded in Lake Baikal, which are represented by Gastropoda $(\sim 82 \%)$ and Bivalvia $(\sim 17 \%)$. Over $60 \%$ of gastropods are endemics in the lake. The Lymnaeidae is the most interesting family among the Palearctic and common Siberian gastropods because some of its species, together with endemics, inhabit both shore-sor zone and open littoral zone of Lake Baikal (Sitnikova et al., 2004; Stift et al., 2004).

In 2014, a huge amount of empty shells of lymnaeids were first found in Spirogyra washed ashore Lake Baikal near the Zarechnoye settlement $(6 \mathrm{~km}$ from the Severobaikalsk town). Timoshkin et al. (2016) suggested that the green algal Spirogyra bloom was induced by the discharge of phosphorus and nitrogenenriched wastewater into the lake.

Lymnaeidae and other animals (amphipods and cottoid fish) have been found in algae washed ashore in the vicinity of the Zarechnoye settlement over the past six years. In 2019, the empty shells of lymnaeids composed $98 \%$ of other animals.

In the open littoral zone of this area, the lymnaeids inhabit mixed (silt, sand and stones) grounds and Spirogyra vegetation. Originally, based on the shell morphology, the lymnaeids were identified as Lymnaea (Peregriana) ovata (Draparnaud, 1805) [currently a junior synonym of Radix balthica (Linnaeus, 1758) according to M.V. Vinarski and Yu.I. Kantor (2016)]. However, the character of the reproductive system as a long spermathecal duct indicates their belonging to Radix auricularia (Linnaeus, 1758).

The shells of the species sampled in 2014 and 2019 had similar sizes; their maximum shell height reached up to $27 \mathrm{~mm}$, resembling the sizes of two-year- old mature specimens. Visual examination of the shell morphology revealed three groups differing in spire height (Fig. 1).

Snails with the shortest spire height were minor in the samples collected in 2019 and were excluded from further analyses. According to the results of the nonparametric analysis (Mann-Whitney test), the shell of the snails with high spire significantly $(\mathrm{p}<0.05)$ differed from snails with low spire. The main characters that subdivided these two groups were also shell height, shell height/spire height and aperture height/ spire height. However, in the plane of two principal components, the snail groups were represented by significantly overlapping clouds (Fig. 2).

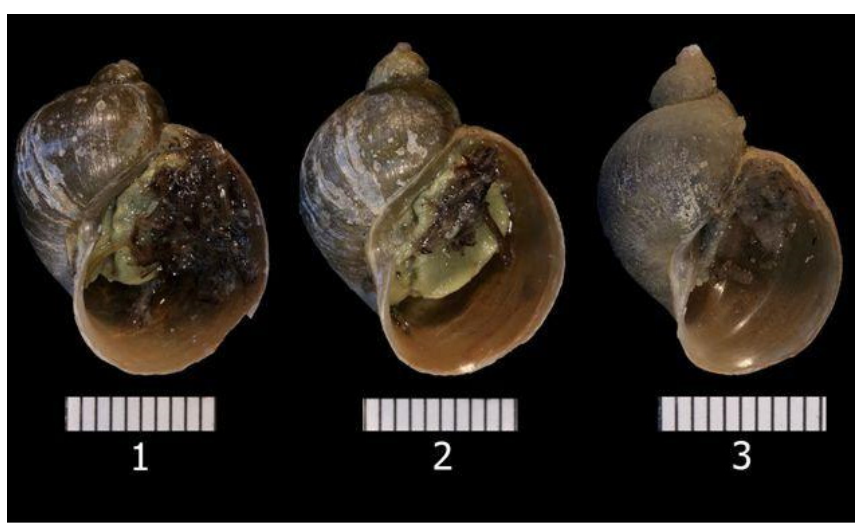

Fig.1. Spire height variations of shells of R. auricularia inhabiting the littoral zone near the Zarechnoye settlement. 
In summary, the snail population of Radix auricularia inhabiting the littoral zone of Lake Baikal near the Zarechnoye settlement shows a high shell variability and is represented by two morphs differing in spire height. These two morphs presumably belong to two snail generations that reproduce in different seasons. Availability of a large number of empty shells of this species attests to their high abundance in the littoral zone of Lake Baikal.

\section{Acknowledgements}

The author thanks Prof O.A. Timoshkin for the initiative to study the gastropods during mass Spirogyra development and Dr T.Ya. Sitnikova for supervision and help in the investigation. This work was supported by the State Task No. 0345-2016-0009 (LIN SB RAS).

\section{References}

Sitnikova T.Y., Starobogatov Y.I., Shirokaya A.A. et al. 2004. Gastropoda. In: Timoshkin O.A. (Ed.), Annotirovannyy spisok fauny ozera Baykal i yego vodosbornogo basseyna [Index of animal species inhabiting Lake Baikal and its catchment area]. Novosibirsk: Nauka. (in Russian)

Stift M., Michel El., Sitnikova T. et al. 2004. Palaeartic gastropod gains a foothold in the dominion of endemics: range expansion and morphological change of Lymnaea (Radix) auricularia in Lake Baikal. Hydrobiologia 513: 101-108. DOI: 10.1023/B:hydr.0000018175.37771.d6

Timoshkin O.A., Samsonov D.P., Yamamuro M. et al. 2016. Rapid ecological change in the coastal zone of Lake Baikal (East Siberia): is the site of the world's greatest freshwater biodiversity in danger? Journal of Great Lakes Research 42(3): 487-497. DOI: 10.1016/j.jglr.2016.02.011

Vinarski M.V., Kantor Yu.I. 2016. Analiticheskiy katalog presnovodnykh i solonovatovodnykh mollyuskov Rossii i sopredel'nykh stran [Analytical catalogue of fresh and brackish water molluscs of Russia and adjacent countries]. Moscow: A.N. Severtsov Institute of Ecology and Evolution Publishing House.

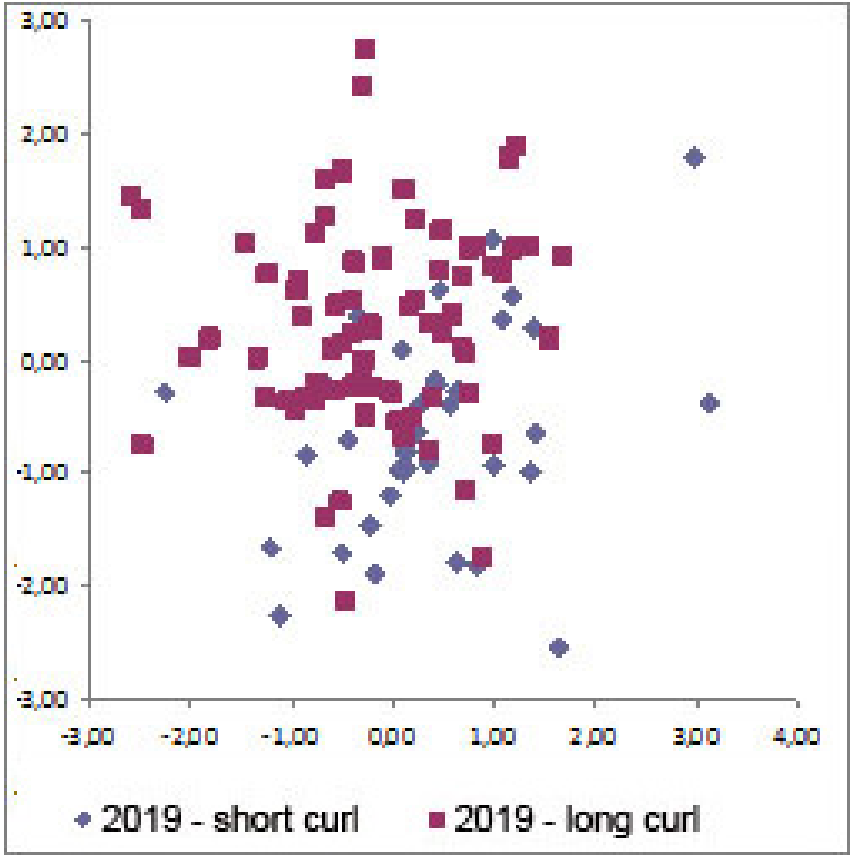

Fig.2. The plot of two groups of R. auricularia (with a low and high spire) in the plane of two principal components. Seven plasticity shell characters and ten shell indices were used. 